\title{
Komunikasi Terapeutik Tenaga Kesehatan (NAKES) Terhadap Pasien Covid-19 di Medan dan Pekanbaru
}

\author{
Dewi Kurniawati \\ Departement of Communication, Universitas Sumatera Utara, Sumatera Utara, Indonesia \\ dewi.kurniawti@usu.ac.id
}

\begin{abstract}
Abstrak
Layanan keperawatan yang bermutu adalah layanan keperawatan yang senantiasa berupaya memenuhi harapan klien sehingga klien akan selalu puas terhadap pelayanan yang diberikan perawat. Pelayanan dan komunikasi yang baik dapat memotivasi pasien untuk segera sembuh ketika terkena penyakit. Pada masa pandemi Covid-19 sekarang banyak tenaga kesehatan (nakes) yang merawat pasien yang terjangkit penyakit akibat virus Covid-19. Para tenaga nakes tidak hanya merawat pasien secara fisik saja tetapi juga perlu menjalin komunikasi dengan baik kepada pasien agar kondisi mental dari pasien juga dapat termotivasi untuk kembali pulih dari sakit. Tujuan dari penelitian ini yaitu menganalisis komunikasi terapeutik tenaga kesehatan dalam pemulihan pasien Covid di kota Medan dan Pekan Baru serta faktor-faktor pendukung dan penghambatnya. Penelitian ini merupakan penelitian kualitatif, data didapatkan dengan melakukan observasi dan wawancara informan secara mendalam. Informan dalam penelitian ini adalah tenaga kesehatan (NAKES) di kota Medan dan Pekan Baru yang akan dipilih sesuai dengan kriteria penelitian. Hasil penelitian menunjukkan bentuk komunikasi terapeutik dilakukan dengan memberikan dukungan psikologis agar memberikan rasa tenang dan percaya diri serta menumbuhkan keyakinan pasien untuk sembuh, menyentuh aspek perasaan supaya pasien lebih rileks dan nyaman untuk meningkatkan imunitas dan mempercepat proses kesembuhan pasien COVID 19. Faktor pendukung dari komunikasi terapeutik ini adalah komunikasi yang positif dari pihak keluarga pasien, sedangkan faktor penghambatnya yaitu banyaknya penerimaan berita negatif yang dapat memicu pikiran buruk pada pasien sehingga kesehatannya menjadi buruk kembali.
\end{abstract}

Kata kunci: Komunikasi Terapeutik, Pasien, Covid-19

\begin{abstract}
Quality nursing services are nursing services that always try to meet client expectations so that clients will always be satisfied with the services provided by nurses. Good service and communication can motivate patients to recover quickly when exposed to illness. During the Covid-19 pandemic, now many health workers (nakes) are treating patients infected with diseases caused by the Covid-19 virus. Health workers not only take care of patients physically but also need to establish good communication with patients so that the mental condition of the patient can also be encouraged to recover from illness. The purpose of this study was to analyze the therapeutic communication of health workers in the recovery of Covid patients in the cities of Medan and Pekanbaru as well as the supporting and inhibiting factors. This research is a qualitative research, data obtained by conducting in-depth observations and interviews with informants. Informants in this study are health workers (NAKES) in the cities of Medan and Pekanbaru who will be selected according to the research criteria. The results showed that the form of therapeutic communication was carried out by providing psychological support in order to provide a sense of calm and confidence as well as growing the patient's self-confidence to recover, touching the emotional aspect so that the patient was more relaxed and comfortable for activities. boost immunity. and accelerate the healing process of COVID 19 patients. The supporting factor for this therapeutic communication is positive communication from the patient's family, while the inhibiting factor is the large number of negative news receipts that can trigger bad thoughts in patients so that their health becomes bad again.

Keywords: Therapeutic Communication, Patients, Covid-19
\end{abstract}




\section{Introduction}

Komunikasi yang baik diperlukan dalam bidang kesehatan antara tenaga kesehatan yang merawat dengan pasiennya. Hal ini di perlukan agar pasien yang sakit mendapatkan motivasi untuk dapat kembali sehat seperti sedia kala. Pada awal Maret 2020 Indonesia mulai terdampak pandemi covid-19 yang membuat banyaknya tenaga kesehatan yang gugur, baik yang menyelamatkan pasien atau pun yang memang ikut terjangkit virus covid-19. Pasien yang terjangkit virus covid-19 awalnya di tandai dengan flu dan demam, kemudian virus tersbut mulai menyerang penyakit bawaan dari pasien. (Yuliana, 2020) Pada data yang diperoleh pada awal tahun 2021 pasien yang terkonfirmasi covid-19 naik menembus 10.000 orang pasien yang sembuh dan presentase untuk kematian mengalami penurunan. Sampai pada hari ini pasien yang positif covid-19 terus bertambah setiap harinya dan selalu diatas 50 orang yang di konfirmasi positif atau pun yang suspek. Pasien yang mendapatkan perawatan di kota Medan sendiri sekarang berjumlah 1301 orang pasien positif Covid dan 518 orang pasien suspek Covid-19.(Https://www.humassumut.id/, 2020)

Pada data yang diperoleh total pasien covid-19 yang paling tinggi di provinsi Riau terdapat di Kota Pekanbaru. Setelah melihat data yang ada, sampai saat ini tercatat sebanyak 31.904 orang yang terkena virus Covid-19 di Riau dan kota Pekanbaru terdapat 15.156 orang yang di konfirmasi positif Covid-19. Pasien yang sembuh dari kota Pekanbaru sudah mencapai 14.000 orang dari awal maraknya kasus ini. (Sarfika et al., 2018)Hal ini yang menarik perhatian peneliti untuk melakukan penelitian tentang Komunikasi terapeutik nakes dalam upaya pemulihan pasien Covid-19 di kota Medan dan Pekanbaru. Penelitian ini bertujuan untuk mengulas komunikasi terapeutik tenaga kesehatan dalam Pemulihan Pasien Covid-19 di Medan dan Pekan Baru, serta faktor-faktor pendukung dan penghambatnya.

\section{Literature Review}

Penelitian terdahulu yang hampir sejenis dilakukan oleh Rizky Hardhiyani Jurusan Psikologi Universitas Negeri Semarang pada tahun 2013. Penelitian ini di latar belakangi oleh fenomena kurangnya motivasi sembuh pasien rawat inap di ruang melati RSUD Kalisari Batang. Penyebabnya antara lain kurang terjalinnya hubungan yang theraupeutic antara perawat dan pasien sehingga menyebabkan pasien merasa kurang termotivasi untuk segera sembuh dari penyakitnya. Penelitian ini bertujuan untuk mengetahui hubungan antara komunikasi therapeutic perawat dengan motivasi sembuh pada pasien rawat inap. Penelitian ini merupakan penelitian kuantitatif korelasional. Subjek penelitian ini berjumlah 127 pasien. 
Teknik sampling yang digunakan adalah accidental sampling. Hasil penelitian menunjukkan bahawa komunikasi theraupeutic perawat semakin tinggi pula motivasi sembuh pasien rawat inap begitu pula motivasi sembuh pasien rawat inap.(Hardhiyani, 2013)

Penelitian selanjutnya, dilakukan oleh Andi Hasan Al Husain Jurnal Ilmu Komunikasi pada tahun 2020. Penelitian ini berjudul Komunikasi Kesehatan Dokter dan Pasien Berbasis Kearifan Lokal di Masa Pandemi. Masa pandemi menimbulkan kekhawatiran bagi tenaga medis tertular virus Covid-19 yang disebabkan tidak terbukanya pasien dalam penggalian informasi pada penyakit yang di derita. Penelitian ini bertujuan untuk menemukan strategi komunikasi interperatif dengan menggunakan teori Dramaturgi dan Goffman serta menggunakan konsep Sipakatau dalam analisisnya. Pemilihan informan dalam penelitian ini adalah tenaga kesehatan yang berprofesi sebagai dokter yang tidak menangani pasien Covid19, untuk penentuannya peneliti menggunakan teknik snowball sampling. Adapun teknik pengumpulan data dengan menggunakan wawancara mendalam melalui videocall Whatsapp, studi pustaka, internet searching. Hasil penelitian ini menunjukkan bahwa presentasi diri dalam back stage tidak terlalu berbeda dengan front stage. Presentasi diri menonjolkan identitas sebagai dokter semestinya. Hal ini dilakukan untuk mendukung sikap kesetaraan dengan pasien dan untuk menunjang keberhasilan dokter dalam menggali informasi dalam anamnesis, dokter menggunakan strategi komunikasi sipakatau. Substansi penelitian ini menemukan konsep baru komunikasi kesehatan antara dokter dan pasien berbasis kearifan lokal Sipakatau dan meberi rekomendasi kepada rumah sakit dan dokter untuk menerapkan konsep komunikasi kesehatan berbasi kearifan lokal.Hal yang membedakan dengan yang penelitian yang akan dilaksanakan adalah pada objek dan lokasi penelitian yang dilakukan.(Husain, 2020)

\section{Komunikasi Antara Pribadi}

Komunikasi antarpribadi bukan sekedar serangkaian rangsangan tanggapan, stimulusrespon akan tetapi serangkaian proses saling menerima dan penyampaian tanggapan yang telah diolah oleh masing-masing pihak. Komunikasi antarpribadi juga berperan untuk saling mengubah dan mengembangkan, perubahan tersebut melalui interaksi dalam komunikasi, pihak-pihak yang terlibat untuk memberi inspirasi, semangat dan dorongan agar dapat merubah pemikiran, perasaan dan sikap sesuai dengan topik yang dikaji bersama. Komunikasi antarpribadi adalah proses pertukaran informasi serta pemindahan pengertian antara dua orang atau lebih di dari suatu kelompok manusia kecil dengan berbagai efek dan umpan balik (feedback). Dalam melakukan komunikasi antar pribadi juga terdapat ciri-ciri dalam menyampaikan pesannya. Menurut Devito dalam buku terdapat ciri-ciri dalam komunikasi 
antar pribadi yang efektif, yaitu ; Keterbukaan (openness); Empati (emphaty); Dukungan (supportiveness); Rasa positif (positiveness); Kesetaraan (equality).(Liliweri, 2015)

\section{Pengungkapan diri (Self Disclosure)}

Komunikasi yang efektif salah satunya akan terjadi apabila seseorang mampu mengungkapkan pikiran dan perasaannya secara terbuka, yang disebut dengan pengungkapan diri. Pengungkapan diri adalah cara individu mengungkapkan perasaan, pikiran, aspirasi dan lainnya tentang diri sendiri kepada orang lain yang bermanfaat bagi perkembangan diri dan komunikasi yang efektif. Self disclosure merupakan proses berbagi informasi yang dilakukan seseorang kepada orang lain dalam bentunk komunikasi. Dalam komunikasi antar pribadi, Joseph Luft menekankan bahwa setiap orang bisa mengetahui dan tidak mengetahui tentang dirinya, maupun orang lain (Liliweri, 2015) .Hal ini digambarkan dalam Johari Window (Jendela Johari) yakni:

\section{Gambar 2.1 Johari Window}

\begin{tabular}{|c|c|}
\hline $\begin{array}{c}\text { I OPEN AREA Known by } \\
\text { ourselves and known by } \\
\text { others }\end{array}$ & $\begin{array}{c}\text { II BLIND AREA Known } \\
\text { by others but not known by } \\
\text { ourselves }\end{array}$ \\
\hline $\begin{array}{c}\text { III HIDDEN AREA } \\
\text { Known by ourselves but } \\
\text { not known by others }\end{array}$ & $\begin{array}{c}\text { IV UNKNOWN AREA } \\
\text { and not known by ourselves }\end{array}$ \\
\hline
\end{tabular}

Berdasarkan konsep tersebut, tingkah laku manusia dapat digambarkan secara skematis seperti terlihat pada skema di atas. Bidang I, yakni Bidang Terbuka (Open Area) menunjukkan bahwa kegiatan yang dilakukan oleh seseorang disadari sepenuhnya oleh yang bersangkutan, juga oleh orang lain, yang berarti terdapat keterbukaan, dengan lain perkataan tidak ada yang disembunyikan kepada orang lain. Bidang II, yakni Bidang Buta (Blind Area) menggambarkan bahwa kegiatan seseorang diketahui oleh orang lain, tetapi dirinya sendiri tidak menyadari apa yang ia lakukan. Bidang III, yakni Bidang Tersembunyi (Hidden Area) yaitu bahwa kegiatan yang dilakukan oleh seseorang disadari sepenuhnya olehnya, tetapi tidak dapat diketahui oleh orang lain. Ini berarti bahwa orang seperti itu bersikap tertutup. Bidang IV, adalah Bidang Tak Dikenal (Unknown Area). Bidang ini menggambarkan bahwa tingkah laku seseorang tidak disadari oleh dirinya sendiri dan tidak diketahui oleh orang lain. (Liliweri, 2015)

\section{Komunikasi Kesehatan}

Komunikasi kesehatan di definisikan sebagai segala aspek dari komunikasi antarmanusia yang berhubungan dengan kesehatan. Secara khusus di definisikan sebagai 
semua jenis komunikasi manusia yang isinya pesannya berkaitan dengan kesehatan (Maisyaroh et al., 2020). Hal ini menjelaskan bahwa komunikasi kesehatan dibatasi pada pesan yang dikirim atau diterima, yaitu ragam pesan berkaitan dengan dunia kesehatan dan faktor-faktor yang mempengaruhi. Komunikasi kesehatan merupakan proses komunikasi melibatkan kesehatan, unsur-unsur atau peserta komunikasi. Dalam komunikasi kesehatan berbagai peserta yang terlibat dalam proses kesehatan antara dokter, pasien, perawat, profesional kesehatan atau orang lain. Komunikasi kesehatan juga dapat dikaitkan dengan mitigasi bencana, mitigasi bencana adalah serangkaian upaya untuk mengurangi resiko bencana, baik melalui pembangunan fisik maupun penyadaran dan peningkatan kemampuan menghadapai ancaman bencana (Peraturan Pemerintah Republik Indonesia Nomor 21 Tahun 2008 Tentang Penyelenggaraan Penanggulangan Bencana, 2008)

\section{Komunikasi Terapeutik}

Komunikasi terapeutik adalah suatu pengalaman bersama antara konselor dalam hal ini konselor bersama dengan residen yang bertujuan untuk menyelesaikan masalah residen. Maksud komunikasi adalah untuk memengaruhi perilaku orang lain. Kalther, dkk (Purwoastuti, 2015) mengatakan bahwa komunikasi terapeutik terjadi dengan tujuan menolong residen yang dilakukan oleh orang-orang yang professional dengan menggunakan pendekatan personal berdasarkan perasaan dan emosi. Di dalam komunikasi terapeutik ini harus ada unsur kepercayaan. Komunikasi terapeutik bukan pekerjaan yang bisa dikesampingkan namun harus direncanakan, disengaja dan merupakan tindakan professional. Akan tetapi jangan sampai karena terlalu asyik bekerja, kemudian melupakan residen sebagai manusia dengan beragam latar belakang dan masalahnya (Suranto, 2005). Keterampilan berkomunikasi merupakan critical skill yang harus dimiliki oleh seorang konselor. Komunikasi ini disebut dengan komunikasi terapeutik merupakan komunikasi yang dilakukan oleh seorang konselor pada saat melakukan intervensi sehingga memberikan khasiat terapi bagi proses penyembuhan residen. Komunikasi terapeutik merupakan kata sifat yang dihubungkan dengan seni dari penyembuhan proses penyembuhan.

Komunikasi dalam bidang keperawatan adalah merupakan suatu dasar dan kunci dari seorang perawat dalam menjalankan tugas-tugasnya. Komunikasi merupakan suatu proses untuk menciptakan hubungan antara perawat dan klien serta dengan tenaga kesehatan lainnya. Tanpa komunikasi seseorang akan merasa terasing dan tanpa komunikasi pula suatu tindakan keperawatan untuk memenuhi kebutuhan klien akan mengalami kesulitan yang sangat berarti.

Dalam ilmu Kesehatan terdapat tujuan komunikasi terapeutik (Damaiyanti, 2010) 
adalah sebagai berikut :

1. Membantu residen untuk memperjelas juga mengurangi beban perasaan dan pikiran serta dapat mengambil tindakan untuk mengubah situasi yang ada bila residen percaya pada hal yang diperlukan.

2. Mengurangi keraguan, membantu dalam hal mengambil tindakan yang efektif.

3. Memengaruhi orang lain, lingkungan fisik dan dirinya sendiri. Menjalin hubungan dengan residen diperlukan komunikasi karena komunikasi adalah hubungan itu sendiri, dimana tanpa komunikasi tersebut hubungan tidak mungkin terjadi. Hubungan yang baik antara konselor dan residen sehingga residen puas dengan pelayanan yang diberikan.

\section{Methods}

Pendekatan yang dilakukan dalam penelitian ini adalah dengan menggunakan pendekatan kualitatif yang mengedepankan aspek naturalistik dari sebuah fenomena yang memiliki latar alamiah tentang apa yang terjadi dan bermaksud untuk memahami fenomena tersebut dengan teliti secara rinci, dituangkan dalam bentuk kata-kata, hingga memberikan gambaran holistik (Moleong, 2017). Penelitian ini berusaha menggali informasi sedalamdalamnya tanpa berusaha mengganggu ataupun mempengaruhi pemikiran informan (Sugiyono, 2011). Peneliti tidak hanya ingin menggambarkan bagaimana komunikasi terapeutik tenaga kesehatan NAKES pada pasien covid-19 namun juga melihat faktor-faktor pendukung dan penghambatnya dengan melakukan observasi serta wawancara kepada informan dalam penelitian ini yaitu para tenaga kesehatan (NAKES) di kota Medan dan Pekan Baru yang akan dipilih sesuai dengan kriteria penelitian. Analisis data dilakukan dengan cara melakukan reduksi, klasifikasi, dan interpretasi data.

\section{Results}

Pada penelitian dan observasi diperoleh data pada awal tahun 2021 pasien yang terkonfirmasi covid-19 naik menembus 10.000 orang pasien yang sembuh dan presentase untuk kematian mengalami penurunan. Sampai pada hari ini pasien yang positif covid-19 terus bertambah setiap harinya dan selalu diatas 50 orang yang di konfirmasi positif atau pun yang suspek. Pasien yang mendapatkan perawatan di kota Medan sendiri sekarang berjumlah 1301 orang pasien positif Covid dan 518 orang pasien suspek Covid-19. Hasil data selanjutnya, yang diobservasi pasien covid-19 yang paling tinggi di provinsi Riau terdapat di Kota Pekanbaru. Setelah melihat data yang ada, sampai saat ini tercatat sebanyak 31.904 orang yang terkena 
virus Covid-19 di Riau dan kota Pekanbaru terdapat 15.156 orang yang di konfirmasi positif Covid-19. Pasien yang sembuh dari kota Pekanbaru sudah mencapai 14.000 orang dari awal maraknya kasus ini.

\section{Gambar 1. Kasus Covid di Kota Pekanbaru}
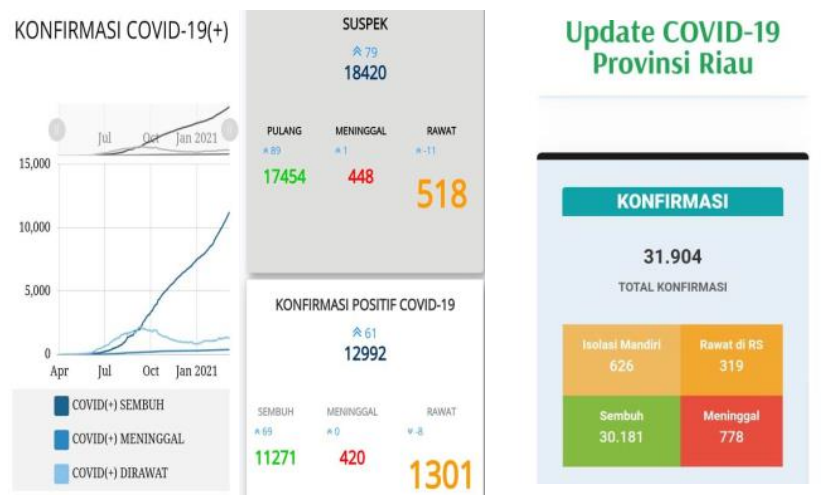
Data sebaran Suspek \& Konfirmasi COVID-19 Provinsi Riau

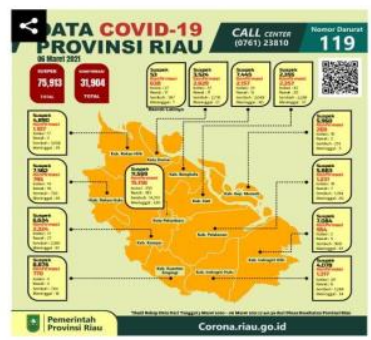

Penelitian yang dilakukan ini akan berjalan lebih kurang selama enam bulan diawali dengan observasi lokasi penelitian dan survey lokasi yang dilakukan guna untuk melihat kondisi dari lokasi yang akan diteliti. Pada penelitian yang dilakukan ditemukan bahwa komunikasi yang positif serta dukungan keluarga di perlukan dalam proses pemulihan pasien covid19. Hal tersebut tidak hanya dapat membangkitkan semangat pasien tetapi dapat juga membantu pemulihan kesehatan mental pasien yang mengalami trauma pasca menjadi penyitas Covid19. Trauma yang dialami pasien bukan hanya karena sakit yang diderita melainkan juga karena kehilangan keluarga dan kerabat terdekat dari pasien, hal tersebut menjadi pemicu fikiran negative sehingga membuat kondisi kesehatannya menjadi menurun.

\section{Discussion}

Para nakes yang menjadi informan peneliti adalah para nakes yang sudah cukup memiliki pengalaman sebagai tenaga kesehatan karena mereka sudah bekerja lebih dari 5 tahun. Para informan telah memiliki pengalaman bekerja yang sudah dalam di harapkan peneliti dapat memberikan informasi lebih dalam mengenai komunikasi teraupetik yang mereka lakukan terhadap pasien khususnya dalam menangani pasien yang terpapar covid 19 atau para penyintas Covid-19. Setelah melakukan wawancara pada Nakes yang sudah di data terdapat berbagai macam informasi yang didapat dari para Nakes mengenai komunikasi teraupetik yang dilakukan para Nakes terhadap pasien yang terjangkit virus Covid19.

Commented [u2]: Pembahasan setidaknya menggambarkan bgmn temuan diulas dengan perspektf/teori. 
Para nakes ini dalam menjalankan aktivitasnya mendampingi pasien yang terpapar covid 19 menerapkan pelayanan yang komunikatif dan persuasif kepada pasien. Petugas memiliki pendekatan komunikasi bersifat efektif untuk menumbuhkan rasa percaya pasien COVID 19 terhadap perawat, karena beberapa pasien menyakini bahwa stresor dapat memperburuk kondisi pasien COVID 19. Pada saat perawat Nakes memberikan dukungan psikologis dengan komunikasi dapat memberikan rasa tenang dan percaya diri serta menumbuhkan keyakinan pasien untuk sembuh, sehingga dengan memberikan kesempatan pasien berkomunikasi rasa dihatinya membuat pasien lebih rileks dan nyaman sehngga meningkatkan imunitas dan mempercepat proses kesembuhan pasien COVID 19. Adapun data para informan yaitu para nakes tersebut adalah sebagai berikut :

\subsection{Data Informan Nakes Medan}

\begin{tabular}{|c|c|c|c|}
\hline Nama & Usia & Lama bertugas & Tempat Tugas \\
\hline Kiki Novita & 32 Tahun & 9 tahun & RS Mitra Sejati \\
\hline Sri Mulyani & 45 tahun & 23 tahun & RS Haji Medan \\
\hline Siti Hajar Rahayu Ningsih & 35 tahun & 10 Tahun & RS Dr. Pirngadi Medan \\
\hline
\end{tabular}

4.2 Data Informan Nakes Pekan Baru

\begin{tabular}{|c|c|c|c|}
\hline Nama & Usia & $\begin{array}{c}\text { Lama } \\
\text { bertugas }\end{array}$ & Tempat Tugas \\
\hline Helena Deli & 35 tahun & 10 tahun & $\begin{array}{c}\text { RSUD Arifin Ahmad Pekan } \\
\text { Baru }\end{array}$ \\
\hline Ratih Indah Sari & 26 tahun & 5 tahun & RS.Awal Bros Panam \\
\hline $\begin{array}{c}\text { Delpida } \\
\text { Fitri,Amd.Keb,STR Keb }\end{array}$ & 27 tahun & 6 Tahun & $\begin{array}{c}\text { RSUD Arifin Ahmad Pekan } \\
\text { Baru }\end{array}$ \\
\hline
\end{tabular}

Banyak pengalaman yang diperoleh para nakes saat merawat pasien covid 19 seperti pengalaman nakes Sri Mulyani yang merawat pasien covid 19 di RS.Haji Medan. Beliau menyatakan ada pasien yang sampai stress saat dirawat karena mereka tidak dapat bertemu keluarga dan orang orang yang mereka. Selain itu pasien banyak yang mengalami depresi Ketika selalu terbayang akan menjadi lebih buruk yang menghantui mereka yaitu perasaan takut meninggal dunia dan lain lain. Ada beberapa kasus yang terdapat pada pasien yang mengalami stress. Salah satunya terdapat pasien yang dengan sengaja membuka APD (alat Pelindung Diri) mereka sehingga mereka bertelanjang diri akibat dari stress dan depresi yang di pikirkan mereka. Namun berkat kesabaran dan kasih sayang dari para nakes di rumah sakit tersebut akhirnya pasien yang mengalami stress itu dapat tenang kembali.

Pengalaman berikutnya disampaikan nakes Helena Deli yang berkerja di RSUD Arifin 
Ahmad Pekan Baru yang membagi pengalamannya merawat pasien covid 19 yang berusaha kabur dari rumah sakit karena merasa khawatir jika meninggal dunia. Pasien tersebut memikirkan seandainya jika beliau meninggal nantinya sebagai muslim yang bersangkutan tidak akan dimandikan, tidak akan dikafani dan tidak disholatkan sebagaimana jenazah biasa pada umumnnya. Pasien tersebut mengalami stress dan depresi bahkan sampai histris berteriak dan menjerit saat dibujuk untuk kembali dirawat. Hal ini pada awalnya cukup merepotkan para nakes dan menguji kesabaran serta emosional dari pada Nakes yang menangani pasien tersebut. Kejadian tersebut juga dialami para Nakes diawal terjadinya pandemic Covid19 yang mana Nakes sendiri juga masih kurang pengetahuan bagaimana cara penanganan Covid19 dan kurangnya peralatan yang memadai pada saat tahun lalu. Namun karena kesabaran para Nakes dan mengingat akan tanggung jawab mereka sebagai tenaga kesehatan pasien harus diberikan perawatan kemudian pasien juga pengertian dengan melakukan komunikasi dan pendekatan-pendekatan kepada pasien agar dapat menenangkannya.

Pengalaman lain disampaikan oleh nakes sebagai informan termuda Ratih Indra Sari yang bertugas di RS Awal Bros Panam Pekan Baru. Beliau menangani pasien yang positif akibat terpapar covid 19 satu keluarga yang terdiri dari suami istri dan satu anak perempuannya. Namun setelah keluar tersebut mendapatkan perawatan yang intensif beberapa hari sang istri meninggal dunia, padahal setelah dilakukan observasi medis secara menyeluruh dan hasil komunikasi dengan pihak keluarga yang memiliki penyakit bawaan (komorbid) adalah sang suami.

Hal ini tentu membuat sang suami menjadi sangat terpukul dan merasa bersalah karena merasa menjadi penyebab kematian istrinya. Suami dari keluarga yang terkan covid19 tersebut mengalami penurunan kondisi dan imunitas tubuh karena tidak memiliki semangat hidup dan pasrah namun berkat motivasi dan komunikasi yang dilakukan Nakes untuk membantu memulihkan psikologi dari bapak tersebut berangsur-angsur kesehatan pasien tersebut menjadi lebih baik. Dari sini dapat kita lihat dalam pemulihan pasien yang terkena covid19 diutamakan adalah komunikasi yang dapat membangkitkan semangat dan memotivasi para pasien agar dapat menjadi semangat pulih kembali kesedia kala.

\section{Conclusion}

Komunikasi terapeutik tenaga kesehatan dalam pemulihan pasien covid-19 di Medan dilakukan dengan memberikan pengertian dan perhatian yang lebih kepada masyarakat yang sedang pemulihan Kesehatan pasca terkena virus Covid-19. Pendekatan yang dilakukan dapat 
membantu residen untuk mengurangi beban perasaan dan pikiran serta dapat mengambil tindakan untuk mengubah situasi yang di alami pasien. Sedangkan komunikasi terapeutik tenaga kesehatan dalam pemulihan pasien covid-19 di Pekanbaru harus memiliki kesabaran dan mampu melakukan pendekatan yang baik kepada pasien agar dapat memotivasi pasien kembali bangkit dan berfikir positif untuk kesahatan mereka. Hasil dari temuan dilapangan faktor pendukung yang dilakukan tenaga kesehatan terhadap pasien, salah satunya adalah komunikasi yang positif dari pihak keluarga pasien yang dapat membantu membangkitkan semangat pasien pasca pemulihan. Sedangkan faktor penghambat dari hasil penelitian yang dilakukan terdapat pada pasien yang terkena Covid-19 adalah banyaknya penyebaran berita negatif yang dapat memicu pikiran buruk pada pasien sehingga kesehatannya menjadi buruk kembali. Sehingga hal tersebut dapat memicu kembali stress dan depresi dari pasien yang mengalami trauma akibat pandemic, hal tersebut dapat memicu menurunnya kesehatan dari pasien.

\section{References}

Damaiyanti, M. (2010). Komunikasi Terapeutik Dalam Praktik Keperawatan. PT.Refika Adimata.

Hardhiyani, R. (2013). Hubungan Komunikasi Therapeutic Perawat Dengan Motivasi Sembuh Pada Pasien Rawat Inap Di Ruang Melati Rumah Sakit Umum Daerah Kalisari Batang.

Https://www.humassumut.id/. (2020). https://www.humassumut.id/. 2020. https://www.humassumut.id/

Husain, A. H. Al. (2020). Komunikasi Kesehatan Dokter dan Pasien Berbasis Kearifan Lokal Sipakatau di Masa Pandemi. Jurnal Ilmu Komunikasi, 18(2), 126. https://doi.org/10.31315/jik.v18i2.3546

Liliweri, A. (2015). Komunikasi Antar Personal - Google Books. Prenadamedia Group.

Maisyaroh, A., Dwi, R., \& Eko, P. (2020). Pedoman Perawat Dalam Merawat Pasien COVID-19 Di Ruang Isolasi. Universitas Jember, 1-23.

Moleong, L. J. (2017). Metode Penelitian Kualitatif (36th ed.). PT. Remaja Rosdakarya Offset.

PERATURAN PEMERINTAH REPUBLIK INDONESIA NOMOR 21 TAHUN 2008 TENTANG PENYELENGGARAAN PENANGGULANGAN BENCANA. (2008).

Purwoastuti. (2015). Ilmu Obstetri \& Ginekologi Sosial Untuk Kebidanan. Pustaka Baru Press.

Sarfika, R., Maisa, E. A., \& Windy Freska. (2018). Komunikasi Terapeutik Dalam Keperawatan. In Andalas University Press. PT.Refika Adimata.

Sugiyono. (2011). Metode Penelitian Kuantitatif, Kualitatif dan R\&D. Afabeta. 
Suranto, L. (2005). Komunikasi Perkantoran. Media Wacana.

Yuliana, Y. (2020). Corona virus diseases (Covid-19): Sebuah tinjauan literatur. Wellness And Healthy Magazine, 2(1), 187-192. https://doi.org/10.30604/well.95212020 